\title{
Male Infertility: Reduction Of Free Radicals Per Action Of Carotenoids
}

\author{
João Ribeiro ${ }^{1}$, Franciele Verzeletti $\mathrm{B}^{2}$ and Rodrigo Poletto $\mathrm{S}^{3}$ \\ ${ }^{1}$ Specialist in Assisted Human Reproduction, Sapientiae Institute, Brazil \\ ${ }^{2}$ Faculdades Pequeno Príncipe, Brazil \\ ${ }^{3}$ Specializing in Medical Clinic, Brazil
}

Submission: Febrauary 22, 2018; Published: March 26, 2018

*Corresponding author: Franciele Bona Verzeletti, Faculdades Pequeno Príncipe, Av. Iguaçu, 333-Rebouças-Curitiba/PR-Brazil, Tel: 41-3310-5031; Email: fra.verzeletti@gmail.com

\begin{abstract}
Infertility is defined as inability of a couple to get a pregnancy after a year of regular intercourse without the use of contraceptive methods. The infertility of a couple caused by male factor only is related to $20-30 \%$ of cases of infertility. Causes of male infertility may be testicular or posttestic, and may be caused by: duct obstruction or ejaculatory disorders; genetic alterations, such as some syndromes (Klinefelter, XX or XYY man syndrome); by external factors of the human body, in other words, environmental factors such as exposure to radiation (radiation and chemotherapy), toxic chemical agents, such as solvents, pesticides and metals such as lead and manganese; occupational diseases, stress, heat exposure in some professions; by the exacerbated consumption of legal and illegal drugs; or idiopathic (with no apparent cause).

The production of free radicals, or reactive oxygen species (ROS), is generally responsible for the damage caused by the most diverse factors on male fertility. All cells of the human body are susceptible caused by ROS, but the sperm cell is particularly vulnerable, both during spermatogenesis, since the germ cells have a high proliferative index, as well as mature spermatozoa, due to the loss of part of the cytoplasm, causing them to have less production of natural antioxidants. Antioxidants are substances that scavenge free radicals, neutralizing their excess and acting in their uptake and inactivation. They are found in abundance in foods containing carotenoids, such as tomato, broccoli, papaya and spinach. The objective of this study was to compile information on the action of carotenoids on the reduction of male infertility and on the improvement of sperm quality, using research tools as Scielo, Pubmed, Elsevier and Lilacs. Many studies about carotenoids shows improvement in the seminal quality, both in human and animal studies, directing experimental treatments in infertile patients, or pointing conditions in serum or seminal plasma of normospermic man, with a larger database in lycopene.
\end{abstract}

Keywords : DHA: Docosa Hexaenoic Acid; AA: Arachidonic Acid; WHO: World Health Organization

Abbreviations : DHA: Docosa Hexaenoic Acid; AA: Arachidonic Acid; WHO: World Health Organization

\section{Introduction}

Infertility, which affects about $15 \%$ of couples, is defined as the inability of a couple to get a pregnancy after a year of regular intercourse without the use of contraceptive methods [1]. The isolated male factor is responsible for about $20 \%$ of the cases and from $30 \%$ to $40 \%$ it is contributory, and are other factors involved [2]. Free Radical is any and all molecules that contain unpaired electrons in their outer orbitals, highly capable of reacting with any compound, becoming highly oxidizing and reducing. Excess production can trigger damage. These causes make the intake of foods containing antioxidants, such as lycopene, an important ally for these free radicals do not cause the destruction of cells $[3,4]$. Oxidative substances are associated with normal physiological function. When infertility results from low seminal quality, it is often due to overproduction of these oxidative substances in semen (especially nitric oxide) [5].

Antioxidants are substances that fight against free radicals, neutralizing their excess, acting on their absorption, inhibiting it or delaying the action of it [6]. Fruits and vegetables contain more than 40 carotenoids that are absorbed and metabolized by humans [4]. The main absorbed carotenoids from the diet are $\alpha$-carotene, $\beta$-carotene, $\beta$-krypto-gezantyne, lutein and lycopene. These representatives contain many double bonds in their molecular structure and, therefore, greater antioxidant potential [7]. The objective of the present study was to perform a literature review on the action of carotenoids in reducing male infertility and improving sperm quality and comparative reading, to infer if 


\section{Global Journal of Reproductive Medicine}

in fact the use of carotenoids in the treatment of infertility causes a real improvement of health reproductive system of man.

\section{Methods}

This research was carried out through a literature review of the last 38 years, with emphasis on studies published since the year 2000, of published works referring to male infertility and the use of carotenoids in the treatment of it. 43 Scientific articles found on websites such as PubMed, Scielo, Elsevier and LILACS were reviewed and of these 43, 26 were selected for the development of the project in order to observe the benefits and possible adverse reactions resulting from the ingestion of carotenoids to improve the seminal quality and reduction of infertility, considering its antioxidant potential. The investigations were carried out using the following keywords: Carotenoids, Antioxidant, reactive oxygen species, infertility, male infertility. They were combined in different ways to ensure a greater amount of bibliographical references and research quality.

\section{Results}

According to data from the literature, it has been observed that some carotenoids have antioxidant action or they develop active roles in male fertility in a significant way, which are lycopene, lutein, pro-vitamin A carotenoids (which include betacarotene), astaxanthin and crocin (Table 1). However, there is a greater number of informative sources of those involving lycopene. Other non-carotenoid organic compounds such as vitamin C (ascorbic acid) and E (alpha-tocopherol), also with antioxidant role, are cited in studies related to the reduction of infertility in man. Zini et al. [8] observed that in human semen samples pre-incubated with lycopene at a dosage of $5 \mu \mathrm{mol} / \mathrm{L}$ and subsequent contact and incubation with hydrogen peroxide, spermatozoa had no motility protection. However, there was less damage caused by hydrogen peroxide to sperm DNA. Hekimoglu et al. [9] performed ischemia/reperfusion studies in mice, a condition that causes a decrease in motility, and showed that lycopene-treated rats had the prevention of decreased motility and in rats with ischemia/reperfusion without testicular torsion there was a reversal of this condition. Also, through this same study, it was observed that in rats with testicular torsion ischemia/reperfusion the administration of lycopene caused two changes to be observed: the reduction of anomalies in spermatozoa (since torser ischemia/reperfusion results in an increase of anomelic spermatozoa by higher Oxigen-reactive species production) and improvement of testicular tissue [9].

Table 1: Correlation of Organic Substance x Result obtained.

\begin{tabular}{|c|c|c|}
\hline Authors & Organic Substance & Action Result \\
\hline Zini et al. [8] & Lycopene; & $\begin{array}{c}\text { No protease in sperm motility, but there was less damage to } \\
\text { sperm DNA. }\end{array}$ \\
\hline Hekimoglu et al. [9] & Lycopene; & $\begin{array}{l}\text { Prevention of decreased motility ischemic/reversion, decreased } \\
\text { anomalies in spermatozoa and improved testicular tissue. }\end{array}$ \\
\hline Mangiagalli et al. [10] & Lycopene; & $\begin{array}{c}\text { Better concentration, volume, motility and viability of } \\
\text { spermatozoa }\end{array}$ \\
\hline \multirow[t]{2}{*}{ Zareba et al. [11] } & Lycopene; & Normal morphology related to the amount of lycopene. \\
\hline & Beta-carotene and lutein; & Better motility. \\
\hline \multirow[t]{2}{*}{ Ghyasvand et al. [7] } & Lycopene; & $\begin{array}{l}\text { Lower concentration in the semen of infertile men;Amounts of } \\
\text { lycopene and lipid peroxidation are inversely proportional. }\end{array}$ \\
\hline & Beta-carotene and Vitamin A; & Greater concentration in normospermic men. \\
\hline \multirow[t]{2}{*}{ Palan \& Naz [12] } & Lycopene; & Lower concentration in semen of infertile men. \\
\hline & Beta-carotene and Vitamin A; & Lower concentration in semen of infertile men. \\
\hline Filipcikova et al. [13] & Lycopene; & Lower difference in DHA/AA ratio (markers of oxidative stress). \\
\hline Safarinejad et al. [14] & Does not correlate with any carotenoid; & $\begin{array}{l}\text { Correlation between infertile men and large difference in DHA / } \\
\text { AA ratio. }\end{array}$ \\
\hline Yamamoto et al. [15] & Lycopene; & $\begin{array}{l}\text { No statistically significant differences in the parameters analyzed } \\
\text { in the samples before and after the ingestion of lycopene. }\end{array}$ \\
\hline Hynstova et al. [16] & Pro-vitamin A; & $\begin{array}{l}\text { Vitamin A deficiency correlates with testicular cytologic } \\
\text { abnormalities }\end{array}$ \\
\hline Clagett-Dame \& Knutson [17] & Pro-vitamin A; & $\begin{array}{l}\text { Vitamin A deficiency correlates with testicular cytologic } \\
\text { abnormalities }\end{array}$ \\
\hline Mitranond et al. [18] & Vitamin A; & $\begin{array}{l}\text { Deficiency causes a fall in the number of germ cells and also in the } \\
\text { quality of the testicular tissues; }\end{array}$ \\
\hline Chihara et al. [19] & Vitamin A; & $\begin{array}{l}\text { Cytological findings similar to those of the authors above } \\
\text { (Mitranond et al.). }\end{array}$ \\
\hline
\end{tabular}


Global Journal of Reproductive Medicine

\begin{tabular}{|c|c|c|}
\hline Boucheron-Houston et al. [20] & Vitamin A; & $\begin{array}{l}\text { Deficiency causes apoptosis early and an increase in } \\
\text { undifferentiated spermatogonia; }\end{array}$ \\
\hline Al-maghrebi et al. [21] & Lutein; & $\begin{array}{l}\text { Lower morphological damage of the seminiferous tubules, } \\
\text { reduced oxidative stress, fewer cells entering apoptosis early; }\end{array}$ \\
\hline Comhaire et al. [22] & Astaxanthin; & $\begin{array}{l}\text { Higher concentration of spermatozoa in ejaculate, reduction of } \\
\text { oxidative stress, increased chance of conception. Patterns such as } \\
\text { motility and morphology did not have significant differences; }\end{array}$ \\
\hline Vahidinia et al. [23] & $\begin{array}{l}\text { Astaxanthin (combined a vitamin C and } \\
\text { E); }\end{array}$ & $\begin{array}{l}\text { Prevention of carotenoid pro-oxidation, increased sperm count, } \\
\text { decreased immobile sperm count and serum increase in the } \\
\text { amount of antioxidants; }\end{array}$ \\
\hline Salahshoor et al. [24] & Crocina; & $\begin{array}{l}\text { Weight and diameter of reduced seminiferous tubules and } \\
\text { improvements in sperm count, concentration, motility, viability } \\
\text { and testosterone concentration; }\end{array}$ \\
\hline Di Mascio et al. [25] & All (except vitamin A e C); & Power to override electrically excited oxygen. \\
\hline
\end{tabular}

Another study with animals, from Mangiagalli et al. [10] Evaluated broiler chickens in order to demonstrate that the ingestion of lycopene, added to the water of these birds, improves the concentration, volume, motility and viability of the spermatozoa of the birds. Zareba et al. [11] in a study with healthy men found that normal morphology parameters were more related to the amount of lycopene involved. Ghyasvand et al. [7] \& Palan \& Naz [7,12]observed that infertile men have a lower concentration of lycopene in semen than normospermic men. Ghyasvand et al. also observed that in the semen of infertile men the amount of lycopene and lipid peroxidation are inversely proportional, since the peroxidation levels were higher in these samples than in those of the normospermic group, due to the lower concentration of antioxidants. Filipcikova et al. [13] measured the levels of docosahexaenoic acid (DHA) and arachidonic acid (AA), markers of oxidative stress, in seminal plasma. After 3 months of lycopene administration, they had a smaller difference in the DHA/AA ratio. Safarinejad et al. [14] conducted a similar study and showed that infertile men have a large difference in DHA/AA ratio.

Differently from other studies, Yamamoto et al. used only groups of infertile men with concentration and motility levels below the threshold, second WHO criteria (World Health Organization), subdivided in control, tomato juice intake and ingestion of lycopene capsules. They found that there were no statistically significant differences in the parameters analyzed in the samples (volume, concentration, motility, among others), because all presented patterns quite close to the previous ones, before the ingestion of lycopene in the two forms chosen for the study [15]. Some studies have shown that deficiency of vitamin A (retinol) correlates with testicular cytological alterations, since some carotenoids are precursors of this vitamin (called pro-vitamin A) [16,17]. Mitranond et al. [18] found that in rats deficient in this vitamin, early in their deprivation, precursor cells were in the lumen of the seminiferous tubules. On subsequent days the tubules decreased in size, the epithelium became thin, the number of germ cells in the tubules decreased dramatically, spermatozoa disappeared, spermatocytes and spermatids decreased and the appearance of abnormal multinucleated giant cells was observed; in rats that did not have vitamin A deficiency these findings were not observed [18]. E More recent studies such as De Chihara et al. [19] had similar cytological findings. Boucheron-Houston et al. went deeper and observed that, with vitamin A deficiency, cells enter apoptosis early and when specific markers were used to identify spermatogenesis stages, an increase in undifferentiated spermatogonia was identified [20].

Palan \& Naz [7] and Ghyasvand et al. [12] observed that infertile men have a lower concentration of beta-carotene and vitamin A (retinol) than normospermic men. Zareba et al. [11] performed an experiment with healthy men and verified that there is a correlation between better motility and amount of beta-carotene and lutein. Al-maghrebi et al. [21] in their ischemia/reperfusion study in rats showed that those untreated specimens underwent morphological and tissue changes with atrophy of the seminiferous tubules and reduction of the number of germ cells. In the lumen of the tubules, debris was observed, but when treated with lutein, they showed lower morphological damages of the seminiferous tubules. The oxidative stress caused by ischemia is also reduced in the specimens that came in contact with lutein, as well as fewer cells entering apoptosis early. Comhaire et al. [22] performed a study with 30 infertile individuals, who were subdivided into placebo and intake of carotenoid Astaxanthin. The individuals who administered the antioxidant for 3 months had a higher concentration of spermatozoa in the ejaculate. However, patterns such as motility and morphology did not have significant differences.

Leukocytes were also observed, with no relevant difference from those who only took the placebo. Oxidative stress had a significant reduction in patients treated with Astaxanthin. Of the 11 patients who ingested the carotenoid in the experiment and who had sex, 6 cases (54.5\%) were able to conceive, and of the 19 placebo patients, only 2 cases (10.5\%) of spontaneous pregnancy during treatment, with a margin of $23.1 \%$ per month of further chance of pregnancy in the Astaxanthin group. Vahidinia et al. [23] also performed an experiment with Astaxanthin, but in combination with vitamins $\mathrm{C}$ and $\mathrm{E}$, to prevent the pro-oxidation of the carotenoid so that it can regenerate and perform its 


\section{Global Journal of Reproductive Medicine}

function along with a calorie restriction diet. After 3 months, they observed that the sperm count was significantly higher in the group where there was caloric restriction and carotenoid intake than in the other groups, and that the number of immobile spermatozoa was lower in the fat restriction group in the antioxidant group and in the group where the two were given together (antioxidants and caloric restriction) than in the control group. There was also a serum increase in the amount of antioxidants in the groups that administered it [23].

Salahshoor et al. [24] in 48 mouse studies, 48 specimens of which 18 were exposed to crocine and nicotine, 18 were exposed only to crocine, 6 were nicotine only and 6 were in the control group. Thus, they observed that in the nicotine group, regardless of the administered dose, the weight and diameter of the seminiferous tubules was reduced in comparison to the other groups, and the only group with crocine presented the best results. Parameters for sperm count, concentration, motility and viability, and testosterone concentration were also deficient in the nicotine group compared to the other groups [24]. Di Mascio et al. [25] (kq) for each carotenoid evaluated, the lycopene with the highest $\mathrm{kq}=31$, Astaxanthin $\mathrm{kq}=24, \beta$-carotene $\mathrm{kq}=14$, lutein $\mathrm{kq}=8$, crocine $\mathrm{kq}=1.1$ and $\alpha$-tocopherol $\mathrm{kq}=0.3$

\section{Discussion}

Lycopene is more relevant for the reduction of reactive oxygen species and for the treatment of infertility, since comparing the literature data, we can first observe a larger database involving this carotenoid, according to the substance that presents one of the highest bioavailabilities in foods, and third is the one that is absorbed by the body in greater quantity. Because lycopene it is a molecule with 11 conjugated and 2 unconjugated double bonds has many electrons that can be donated to free radicals, which results in its neutralization [26]. The withdrawal potential of electronically excited oxygen molecules from lycopene is 1.3 times more potent than Astaxanthin, twice as much as betacarotene, four times as high as lutein, 30 times greater than crocine and up to a hundredfold potent than $\alpha$-tocopherol. Studies have shown that lycopene can alter motile, sperm concentration, vitality, and other characteristics of lycopene, which correlate lycopene dosages with better sperm and sperm DNA (8; 9; 10). Ghyasvand et al. [7] and Palan \& Naz [12] observed that in infertile men lycopene is found in smaller amounts. Yamamoto et al. [15] in contradiction, did not obtain statistically significant data regarding the abovementioned standard. However, studies show that the interactions of different carotenoids bring greater benefits to the body. Some carotenoids, such as $\alpha$-carotene, $\beta$-carotene and $\beta$-cryptoxanthin are pro-vitamin $A$, being these precursors of vitamin A [6], other studies have observed that in the deprivation of vitamin A the testicular cytological findings contained morphological alterations in several patterns [16-19].

In the present study, the presence of the precursor cells in the lumen of the seminiferous tubules, decreased diameter of the tubules, thin epithelium, giant multinucleated cells, etc. Boucheron-Houston et al. [20] In addition to the above vitamin A findings, observed that cells enter apoptosis early when vitamin deficiency. Low concentrations of Vitamin A and $\beta$-carotene were found in the semen of infertile men and large amounts of Vitamin $A$ and $\beta$-carotene were related to normospermic men. Other carotenoids have been found to be beneficial for male reproductive health. It has been observed that lutein assists in improving motility and increasing the concentration of spermatozoa in the ejaculate. The use of Astaxanthin was also correlated with the increase in sperm concentration in the ejaculate and in addition to this, at a higher pregnancy rate and decreased immobile sperm count. Salahshoor et al. [24] in the study with crocin had similar results to these carotenoids mentioned above.

\section{Conclusion}

This research showed that carotenoids play a fundamental role in the capture and neutralization of reactive oxygen species. Due to this factor, they interfere positively in the male reproductive system, improving infertility, which are generated by several causes (endocrine, testicular, obstructive, genetic and idiopathic). Among the carotenoids mentioned in the study, lycopene has the highest antioxidant potential, it also has a larger database and more substantial information regarding its structure, absorption, action and potential for the removal of reactive oxygen species. The combination of the present content in the various studies used as a basis for the development of this work allowed us to conclude that carotenoids, alone or interacting with other compounds, offer benefits in terms of reestablishment of male fertility and no contraindication to its use, since they do not present deleterious effects on the organism or reproductive health.

\section{References}

1. Pasqualotto FF (2007) Investigação e reprodução assistida no tratamento da infertilidade masculina. Revista Brasileira de Ginecologia e Obstetrícia 29: 103-112.

2. Sharlip ID, Jarow JP, Belker AM, Lipshultz LI, Sigman M, et al. (200) Best pratice policies for male infertility. Fertil Steril 77(5): 873-82.

3. Durairajanayagam D, Agarwal A1, Ong C, Prashast P (2014) Lycopene and Male Infertility. Asian J Androl 16(3): 420-425.

4. Gajowik A, Dobrzyńska MM (2014) Lycopene-antioxidant with radioprotective and anticancer properties. A review. Rocz Panstw Zakl Hig 65(4): 263-271.

5. Carvalho FO, Ferreira JDJ, Silveira NA, Freneau GE (2002) Oxidative effect of nitric oxide and male infertility. Jornal Brasileiro de Patologia e Medicina Laboratorial. 38: 33-39.

6. Rodriguez-Amaya DB, Kimura M, Amaya-Farfan J (2008) Fontes brasileiras de carotenoides: tabela brasileira de composição de carotenoides em alimentos. Ministério do Meio Ambiente- MMA. pp. 100

7. Ghyasvand T, Goodarzi MT, Amiri I, Karimi J, Ghorbani M (2015) Serum levels of lycopene, beta-carotene, and retinol and their correlation with sperm DNA damage in normospermic and infertile man. Int J Reprod Biomed (Yazd) 13(12): 787-792. 


\section{Global Journal of Reproductive Medicine}

8. Zini A, San Gabriel M, Libman J (2010) Lycopene supplementation in vitro can protect human sperm deoxyribonucleic acid from oxidative damage. Fertil Steril 94(3): 1033-1036.

9. Hekimoglu A, Kurcer Z, Aral F, Baba F, Sahna E, et al. (2009) Lycopene, na antioxidant carotenoid, attenuates testicular injury, caused by ischemia/reperfusion in rats. Tohoku J Exp Med 218(2): 141-147.

10. Mangiagalli MG, Martino PA, Smajlovic T, Cavalchini LG, Marelli SP (2010) Effect of lycopene on semen quality, fertility and native immunity of boiler breeder. Br Poult Sci 51(1): 152-157.

11. Zareba P, Colaci DS, Afeiche M, Gaskins AJ, Jorgensen N et al. (2013) Semen quality in relation to antioxidant intake in a healthy male population. Fertil Steril 100(6): 1572-1579.

12. Palan P, Naz R(1996) Changes in various antioxidant levels in human seminal plasma related to immunoinfertility. Arch Androl 36(2): 139143.

13. Filipcikova R, Oborna I, Brezinova J, Novotny J, Wojewodka G, et al. (2015) Lycopene improves the distorted ratio between AA/DHA in the seminal plasma of infertile males and increses the likelihood of successful pregnancy. Biomed Pap Med Fac Univ Palacky Olomouc Czech Repub 159(1): 77-82.

14. Safarinejad MR, Hosseini SY, Dadkhah F, Asgari MA (2010) Relationship of omega- 3 and omega- 6 fatty acids with semen characteristics, and anti-oxidant status of seminal plasma: A comparison between fertile and infertile man. Clin Nutr 29(1): 100-105.

15. Yamamoto Y, Aizawa K, Mieno M, Karamatsu M, Hirano Y, et al. (2017) The effects of tomato juice on male infertility. Asia Pac J Clin Nutr 26(1): 65-71.

16. Hynstova V, Sterbova D, Klejdus B, Hedbavny J, Huska D, et al. (2017) Separation, identification and qualification of carotenoids and chlorophylls in dietary supplements containing Chlorella vulgaris and Spirulina platensis using high performance thin layer chromatography. J Pharm Biomed Anal 148: 108-118.

17. Clagett-Dame M, Knutson D (2011) Vitamin A in reproduction and development. Nutrients 3(4): 385-428.
18. Mitranond V, Sobhon P, Tosukhowong P, Chindaduangrat W (1979) Cytological changes in the testes of vitamin-A-deficient rats. Acta Anat (Basel) 103(2): 159-168.

19. Chihara M, Otsuka S, Ichii O, Kon Y (2013) Vitamin A deprivation affects the progression of the spermatogenic wave and initial formation of the blood-testis barrier, resulting in irreversible testicular degeneration in mice. J Reprod Dev 59(6): 525-535.

20. Boucheron-Houston C, Canterel-Thouennon L, Lee TL, Baxendale V, Nagrani S, et al. (2013) Long-term Vitamin-A-deficiency induces alteration of adult mouse spermatogenesis and spermatogonial differentiation: direct effect on spermatogonial gene expression and indirect effects via somatic cells. J Nutr Biochem 24(6): 1123-1135.

21. Al-Maghrebi M, Renno WM, Al-Somali HF, Botras MS, Qadhi IN (2016) Lutein modulates transcription dysregulation of adhesion molecules and spermatogenesis transcription factors induced by testicular ischemia reperfusion injury: it could be safe. Naunyn Schmiedebergs Arch Pharmacol 389(5): 539-551.

22. Comhaire FH, El Garem Y, Mahmoud A, Eertmans F, Schoonjans F (2005) Combined conventional/antioxidant Astaxanthin treatment for male infertility: a double blind, randomized trial. Asian J Androl 7(3): 257-262.

23. Vahidinia A, Rahbar AR, Shakoori Mahmoodabadi MM (2016) Effects of Astaxathin, Vitamin E, and Vitamin C in combination with calorie restriction on sperm quality and quantity in male rats. J Diet Suppl 14(3): 252-263.

24. Salahshoor MR, Khazaei M, Jalili C, Keivan M (2016) Crocin improves damage induced by nicotine on a number of reproductive parameters in male mice. Int J Fertil Steril 10(1): 71-78.

25. Di Mascio P, Kaiser S, Sies H (1989) Licopene as the most efficient biological carotenoid singlet oxygen quencher. Arch Biochem Biophys 274(2): 532-538.

26. Rao AV, Agarwal S (1999) Role of lycopene as antioxidant carotenoid in the prevention of chronic diseases: a review. Nutrition Research 19(2): 305-323.

Your next submission with Juniper Publishers
will reach you the below assets
- Quality Editorial service
- Swift Peer Review
- Reprints availability
- E-prints Service
- Manuscript Podcast for convenient understanding
- Global attainment for your research
- Manuscript accessibility in different formats
( Pdf, E-pub, Full Text, Audio)
- Unceasing customer service
Track the below URL for one-step submission
https://juniperpublishers.com/online-submission.php

